\title{
DECLARAÇÃO DE BRASÍLIA
}

Nós, congressistas reunidos no III Congresso Ibero-Americano de Direito Sanitário, entre 2 a 4 de outubro de 2013, ano do Jubileu de Prata da Constituição da República Federativa do Brasil que instituiu o Direito à Saúde como um direito dos cidadãos e dever do Estado, declaramos que:

a) O direito à saúde, como um direito humano e fundamental inscrito nos principais tratados de direitos humanos e cartas constitucionais de diversos países, e a assistência à saúde não devem estar submetidos à lógica do mercado, considerando o dever de universalidade e integralidade da assistência dos Estadosnacionais;

b) Os direitos da saúde conquistados pelos povos não devem jamais retroceder, como direitos humanos fundamentais, mesmo em vista de crises econômicas ou políticas;

c) Os direitos da saúde requerem, para sua efetividade, que os governos viabilizem o acesso aos avanços científicos e às novas tecnologias em saúde, considerando o direito humano de acesso ao progresso científico e a imprescindibilidade desses recursos para a boa qualidade da prestação sanitária;

d) Todos os Estados devem garantir o máximo de recursos internos e internacionais para o adequado financiamento do setor da saúde;

e) Os governos devem conhecer os próprios conflitos presentes na realização do direito à saúde e viabilizar instâncias, instrumentos e mecanismos para enfrentá-los no âmbito do próprio sistema de saúde, buscando responder e encaminhar de forma democrática e eficiente as demandas sociais de saúde.

f) Resulta necessária a expansão dos conhecimentos em Direito Sanitário em nível de graduação e pós-graduação nos países da região ibero-americana.

Brasília, 4 de outubro de 2013 III Congresso Ibero-Americano de Direito Sanitário 


\section{DECLARACIÓN DE BRASILIA}

Los congresistas que se reunieron en el III Congreso Iberoamericano de Derecho Sanitario, entre 2 y 4 de octubre de 2013, año del Jubileo de Plata de la Constitución de la República Federativa del Brasil, que estableció el derecho a la Salud como un derecho de los ciudadanos y deber del Estado, declaramos que:

a) El derecho a la salud, como un derecho humano y fundamental inscrito en los principales tratados de derechos humanos y cartas constitucionales de diversos países, y la asistencia a la salud no deben ser sometidos a la lógica del mercado, teniendo en cuenta el deber de universalidad e integralidad de la asistencia de los Estados nacionales;

b) Los derechos en la salud conquistados por el pueblo no deben nunca retroceder, como derechos humanos fundamentales, incluso ante las crisis económicas o políticas;

c) Los derechos en la salud requieren, para su efectividad, que los gobiernos hagan viable el acceso a los avances científicos y a las nuevas tecnologías en salud, teniendo en cuenta el derecho humano de acceso al progreso científico y la alta dependencia de esos recursos para la buena calidad de la prestación sanitaria;

d) Todos los Estados deben garantizar el máximo de los recursos internos e internacionales a la financiación adecuada del sector salud;

e) Los gobiernos deben conocer sus propios conflictos, presentes en la realización del derecho a la salud, y habilitar instancias, instrumentos y mecanismos para resolverlos en el marco del propio sistema de salud, buscando responder y encauzar democrática y eficientemente a las demandas sociales de salud.

f) Resulta necesaria la expansión de los conocimientos en Derecho Sanitario a nivel de graduación y pos-graduación en los países de la Región Iberoamericana.

Brasília, 4 de octubre de 2013 